\title{
Penerapan Project Based Learning Terintegrasi STEM untuk Meningkatkan Literasi Sains Siswa Ditinjau dari Gender
}

\author{
Jaka Afriana $^{1 *}$, Anna Permanasari ${ }^{2}$, Any Fitriani ${ }^{3}$ \\ ${ }^{123}$ Program Studi Pendidikan IPA, Sekolah Pascasarjana, Universitas Pendidikan Indonesia. Jalan Dr. \\ Setiabudhi No. 229 Bandung 40154, Indonesia \\ * Korespondensi Penulis. Email: jakafisika04@gmail.com
}

\begin{abstract}
Abstrak
Penelitian ini bertujuan untuk menyelidiki pengaruh gender siswa terhadap literasi sains melalui pembelajaranproject based learning (PjBL) yang diintegrasikan dengan science, technology, engineering, dan mathematics (STEM) pada tema pencemaran udara. Metode penelitian yang digunakan adalah pre-eksperimen dengan desain The static Group Pretest-Posttest Designyang dilaksanakan di kelas VII SMP Islam Terpadu di kabupaten Sukabumi sebanyak 57 siswa yang terdiri dari kelas laki-laki (29 orang) dan kelas perempuan ( 28 orang). Pengumpulan data dilakukan dengan menggunakan tes awal dan tes akhir untuk literasi sains dan angket siswa terhadap PjBL STEM. Berdasarkan hasil analisis data diperoleh peningkatan literasi sains siswa kelompok laki-laki dan kelompok perempuan sama-sama mengalami peningkatan dengan rerata $N \_$Gainyaitu 0,36 dan 0,31pada kategori sedang untuk aspek pengetahuan dan kompetensi. Hasil uji-t menunjukkan bahwa peningkatan literasi sainskelas laki-laki dan kelas perempuan berbeda tidak signifikan.Pada aspek sikap sains, kelas perempuan berbeda signifikan dari kelas laki-laki.Tanggapan siswa secara keseluruhan menunjukkan hampir seluruh siswa menyatakan senang dengan pembelajaran PjBL STEM dan memperoleh pengalaman yang sangat berkesan mengikuti tahapan pembelajaran sehingga menimbulkan motivasi dan minat dalam belajar.
\end{abstract}

Kata Kunci: project based learning, STEM, literasi sains,gender

\section{Implementation Project-Based Learning Integrated STEM to Improve Scientific Literacy Based on Gender}

\begin{abstract}
This study aims to investigate the influence of gender on the students' science literacy through project based learning (PjBL) integrated science, technology, engineering, and mathematics (STEM) approach forstudents junior high school. The theme used in this project was air pollution. The method used was pre-experimental design the static group pretest-posttest design and was implemented in grade VII of the Integrated Islamic school at Sukabumi. The subjects were 57 students divided into two, malegroup $(N=29)$ and female group $(N=28)$. The data collection was done by pretest and posttest for scientific literacy and students' responses to the PjBL STEM. Based on the result it were obtained that an average $N_{-}$Gain of male group was 0.36 and was 0.31 for female group with medium category on knowledge and competence. T-test results showed that increasing scientific literacy male group and female of different classes do not signifikan. Attitude aspect of science, female group differ significantly from male group. The student responses showed almost all of the students agreed to the implementation of the PJBL STEM and gain great new experiences that stages of learning that lead to be interested and motivated in learning.
\end{abstract}

Keywords: project-based learning, STEM, scientific literacy, gender

How to Cite: Afriana, J., Permanasari, A., \& Fitriani, A. (2016). Penerapan project based learning terintegrasi STEM untuk meningkatkan literasi sains siswa ditinjau dari gender. Jurnal Inovasi Pendidikan IPA, 2(2), 202212. doi:http://dx.doi.org/10.21831/jipi.v2i2.8561

Permalink/DOI: http://dx.doi.org/10.21831/jipi.v2i2.8561 


\section{PENDAHULUAN}

Literasi sains dianggap sebagai hasil belajar kunci dalam pendidikan untuk usia 15 tahun bagi semua peserta didik, terlepas dari apakah peserta didik berminat untuk meneruskan pelajaran sains itu ataukah tidak setelah itu (Toharudin et al., 2011, p.12). Berdasarkan capaian literasi sains pada PISA tahun 2012 yang diikuti oleh 65 negara, Indonesia menempati urutan kedua dari bawah. Skor rata-rata siswa Indonesia pada literasi sains 382 di bawah skor rata-rata PISA, yaitu 501 (OECD, 2014, p.5). Rendahnya kemampuan literasi sains siswa merupakan suatu alasan yang melandasi pemerintah melakukan revisi kurikulum 2006 ke 2013 (Odja \& Payu, 2014, p. 41). Oleh karena itu, diperlukan pembelajaran sains yang dapat menumbuhkan literasi sains siswa.

Pembelajaran sains pada kurikulum 2013 telah memberikan acuan dalam pemilihan model pembelajaran yang sesuai dengan pendekatan saintifik. Model pembelajaran yang dimaksud meliputi: Project Based Learning (PjBL), Problem Based Learning (PBL), atau Discovery Learning. Pemilihan model pembelajaran diserahkan kepada guru dengan menyesuaikan dengan karakteristik materi ajar. Pembelajaran berbasis proyek merupakan model pembelajaran yang berpusat pada siswa dan memberikan pengalaman belajar yang bermakna bagi siswa. Pengalaman belajar siswa maupun perolehan konsep dibangun berdasarkan produk yang dihasilkan dalam proses pembelajaran berbasis proyek.

Penerapan PjBL dalam pembelajaran sains dari hasil penelitian dapat meningkatkan hasil belajar kognitif (Baran \& Maskan, 2010, p.252), membentuk sikap dan prilaku peduli terhadap lingkungan (K1lınç, 2010, p. 504; Tseng, Chang, Lou, \& Chen, 2013, p. 87), keterampilan proses sains (Özer \& Özkan, 2012, p.133), dan pembelajaran yang efektif (Cook, Buck, \& Park Rogers, 2012, p. 26; Movahedzadeh, Patwell, Rieker, \& Gonzalez, 2012, p. 7) (Movahedzadeh et al., 2012, p. 7). Pembelajaran berbasis proyek lebih sesuai dalam pembelajaran interdisipliner karena secara alami melibatkan banyak keterampilan akademik yang berbeda, seperti membaca, menulis, dan mate-matika serta sesuai dalam membangun pema-haman konseptual melalui asimilasi mata pelajaran yang berbeda (Capraro, Capraro, Morgan, \& Slough, 2013, p. 52), sehingga $\mathrm{PjBL}$ diharapkan dapat membangun literasi sains siswa.

Selain PjBL, pembelajaran saat ini perlu mengikuti perkembangan zaman di era globalisasi salah satunya dengan mengintegrasikan Science, Technology, Engineering, dan Mathematics (STEM). Keterkaitan antara sains dan teknologi maupun ilmu lain tidak dapat dipisahkan dalam pembelajaran sains. STEM merupakan displin ilmu yang berkaitan erat satu sama lain.Sains memerlukan matematika sebagai alat dalam mengolah data, sedangkan teknologi dan teknikmerupakan aplikasi dari sains. Pendekatan STEM dalam pembelajaran diharapkan dapat menghasilkan pembelajaran yang bermakna bagi siswa melalui integrasi pengetahuan, konsep, dan keterampilan secara sistematis. Beberapa manfaat dari pendekatan STEM membuat siswa mampu memecahkan masalah menjadi lebih baik, inovator, inventors, mandiri, pemikir logis, dan literasi teknologi (Morrison dalam Stohlmann, Moore, \& Roehrig, 2012, p. 29).

Cara yang lebih komprehensif untuk menanamkan keempat disiplin ke satu sama lain dengan mengajarkannya sebagai subjek yang terintegrasi. Misalnya, ada konten teknologi, teknik, dan matematika dalam sains, sehingga guru sains akan mengintegrasikan $\mathrm{T}$, E, dan $\mathrm{M}$ ke dalam S (Dugger, 2010, p. 5; Firman, 2015, p.5). Sains dan matematika dipandang tepat untuk menjadi kendaraan membawa pendidikan STEM, sebab kedua mata pelajaran ini merupakan mata pelajaran pokok dalam pendidikan dasar dan menengah, dan menjadi landasan bagi peserta didik untuk memasuki karir dalam disiplin-disiplin STEM yang dipandang fundamental bagi inovasi teknologi dan produktivitas ekonomi (Firman, 2015, p.6).

Pembelajaran STEM perlu menekankan beberapa aspek dalam proses pembelajaran (NRC, 2011, pp.3-5) diantaranya: (1) mengajukan pertanyaan (science) dan mendefinisikan masalah (engineering); (2) mengembangkan dan menggunakan model; (3) merencanakan dan melakukan investigasi; (4) menganalisis dan menafsirkan data (mathematics); (5) menggunakan matematika; teknologi informasi dan komputer; dan berpikir komputasi; (6) membangun eksplanasi (science) dan merancang solusi (engineering); (7) terlibat dalam argumen berdasarkan bukti; (8) memperoleh, mengevaluasi, dan mengkomunikasikan informasi.

Penelitian tentang integrasi STEM dalam $\mathrm{PjBL}$ terhadap literasi sains masih jarang dilakukan. Hasil penelitian Tseng et al., (2013, p. 87) 
mengungkapkan bahwa PjBL terintegrasi STEM dapat meningkatkan minat belajar siswa, pembelajaran menjadi lebih bermakna, membantu siswa dalam memecahkan masalah dalam kehidupan nyata, dan menunjang karir masa depan. Selain itu, STEM dalam PjBL memberikan tantangan dan memotivasi siswa karena melatih siswa berpikir kritis, analisis dan meningkatkan keterampilan berfikir tingkat tinggi (Capraro et al., 2013, p. 2). Melalui pembelajaran STEM, siswa memiliki literasi sains dan teknologi yang nampak dari membaca, menulis, mengamati, serta melakukan sains sehingga dapat dijadikan bekal untuk hidup bermasyarakat dan memecahkan permasalahan yang dihadapi dalam kehidupan sehari-hari yang terkait dengan bidang ilmu STEM (Mayasari et al., 2014, p.376).

Hasil penelitian lain terkait dengan literasi sains maupun bidang STEM dengan menganalisis adanya perbedaan gender. Laporan PISA 2012 mengemukakan bahwa laki-laki unggul dibandingkan perempuan dalam kinerja matematika. Perempuan merasa kurang termotivasi untuk belajar matematika dan kurang yakin pada kemampuannya dibandingkan dengan laki-laki. Hal ini yang menjadi tantangan berat untuk mencapai kesetaraan gender pada bidang pekerjaan STEM di masa depan (OECD, 2014, p.9). Untuk bidang teknologi dan engineering, (Hango, 2013, p. 7) menyebutkan bahwa bidang STEM didominasi oleh laki-laki. Perempuan kebanyakan memilih bidang biologi atau sains, sehingga lebih sedikit memilih bidang engineering, ilmu komputer, dan matematika. Jika lakilaki lebih banyak memilih dalam bidang STEM, itu bukan karena laki-laki memiliki skor PISA lebih baik daripada perempuan. Bahkan, ketika diukur kemampuan matematika digabungkan dengan variabel lain, perbedaan gender tetap signifikan.

National Research Council (2011, p.17) menyatakan bahwa dalam pembelajaran STEM siswa memiliki kesempatan untuk belajar sains, matematika, dan teknik dengan mengatasi masalah yang memiliki aplikasi di dunia nyata. Dalam kelas STEM, siswa dituntut memecahkan masalah dunia nyata dan terlibat dalam illdefined tasks menjadi well-defined outcome melalui kerja sama dalam kelompok (Han, Capraro, \& Capraro, 2015, p. 1093). Pendidikan STEM menjadi prioritas utama dalam memecahkan isu-isu global dan masalah yang dihadapi dunia saat ini misalnya: pemanasan global, pencemaran udara dan air, air minum yang bersih, dan keamanan pangan (Reeve, 2015, p.12).

Tema pencemaran udara merupakan salah satu materi yang diakomodasi dalam pembelajaran sains di SMP pada kompetensi dasar 3.9 mendeskripsikan pencemaran dan dampaknya bagi makhluk hidup, dan 3.10 mendeskripsikan tentang penyebab terjadinya pemanasan global dan dampaknya bagi ekosistem. Pencemaran udara menjadi masalah di dunia nyata yang memerlukan pemecahan masalah dalam pembelajaran sains. Pencemaran udara berasal dari aktivitas manusia serta peristiwa alam. Industri, konstruksi, pembangkit listrik, transportasi, dan pertanian adalah beberapa contoh kegiatan manusia yang dapat mencemari udara (Glencoe, 2005; Raven et al., 2013). Akibat yang ditimbulkan oleh pencemaran udara menurut Kemdikbud (2013, pp.235-236) antara lain: terganggunya kesehatan manusia, rusaknya bangunan, terganggunya pertumbuhan tananam, dan adanya peristiwa efek rumah kaca (green house effect). Efek rumah kaca memberikan kontribusi terbesar dalam pencemaran udara. Peristiwa efek rumah kaca disebabkan oleh aktivitas manusia sendiri termasuk pembakaran bahan bakar fosil dan penggundulan hutan yang menghasilkan meningkatnya konsentrasi gas rumah kaca di atmosfer. Gas rumah kaca memerangkap energi panas sehingga suhu bumi meningkat dengan cepat. Ilmuwan memprediksi bahwa ekosistem kompleks yang telah dikembangkan dan diversifikasi selama puluhan juta tahun tidak dapat dipertahankan (Hewitt et al., 2013, p.764). Kesadaran akan pentingnya menjaga kelestarian lingkungan hidup perlu ditanamkan kepada siswa sejak dini sebagai langkah preventif dalam menghadapi isu-isu lingkungan yang terjadi.

Berdasarkan permasalahan tersebut sangat menarik diteliti pembelajaran yang dapat membantu siswa dalam meningkatkan literasi sains berdasarkan gender siswa. Masalah penelitian ini adalah (1) Apakah perbedaan gender siswa berpengaruh terhadap literasi sains siswa pada tema pencemaran udara?; (2) Bagaimanakah tanggap-an siswa terhadap pembelajaran $\mathrm{PjBL}$ STEM. Adapun pembelajaran PjBL STEM dilakukan dalam lima tahap (Laboy-Rush, 2010), yaitu tahap reflection, tahap research, tahap disco-very, tahap application, dan tahap communication.

\section{METODE}

Penelitian ini akan dilaksanakan dengan metode penelitian pre-eksperimental 
(Sukmadinata, 2010, p.208; Sugiyono, 2013, p.109) dengan penerapan pembelajaran PjBL STEM pada kedua kelas. Waktu penelitian dari November 2015 hingga Maret 2016 bertempat di SMP Islam Terpadu (IT) Adzkia Sukabumi, Jawa Barat.

Subjek penelitian ini adalah siswa kelas VII semester 2 pada SMP IT Adzkia Sukabumi pada tahun ajaran 2015/2016 yang akan mengikuti pelajaran sains pada tema pencemaran udara.Pengelompokkan kelas di SMP IT Adzkia berdasarkan jenis kelamin (gender), dimana kelas laki-laki dan kelas perempuan dibuat terpisah. Pemilihan kelas laki-laki(VII D) dan kelas perempuan(VII B) berdasarkan saran dari guru bidang studi dan perizinan dari pihak managemen sekolah yang bersangkutan mengacu pada kemampuan yang dimiliki siswa. yang diberi perlakuan pembelajaran PjBL STEM.

Penelitian ini dilaksanakan dengan rancangan The Static Group Pretest-Posttest Design (Sukmadinata, 2010, p.209; Fraenkelet al., 2011, p.270). Static Group dalam penelitian ini diasumsikan kelas yang mempunyai kemampuan setara dan diajar oleh guru yang sama. Treatment dilakukan dengan memberikan pembelajaran project based learning ( $\mathrm{PjBL})$ terintegrasi science, technology, engineering, dan mathematics (STEM).

Prosedur penelitian meliputi tahap perencanaan, tahap pelaksanaan dan tahap akhir. Tahap perencanaan yaitu pembuatan Rencana Pelaksanaan Pembelajaran (RPP) dan Lembar Kerja Siswa (LKS) PjBL STEM, soal literasi sains tema pencemaran udara dan studi literatur gender siswa dalam pembelajaran sains. Tahap pelaksanaan dengan memberikan perlakuan pembelajaran PjBL STEM. Sedangkan tahap akhir dengan melakukan analisis data, pembahasan dan menarik kesimpulan penelitian.

Data dalam penelitian ini berupa data tes literasi sains dan data tanggapan siswa terhadap pembelajaran PjBL STEM. Instrumen penelitian berupa tes tertulis literasi sains memuat aspek pengetahuan dan kompetensi, lembar angket skala sikap sains, dan lembar tanggapan siswa terhadap PjBL STEM.

Instrumen yang digunakan adalah soal literasi menurut framework PISA 2012 yang dikaitkan dengan aspek STEM dan angket skala sikap untuk mengetahui tanggapan siswa. Tes literasi sains tidak hanya mengukur tingkat pemahaman siswa terhadap pengetahuan sains, tetapi juga pemahaman terhadap aspek kompetensi sains, kemampuan untuk mengaplikasikan pengetahuan, dan sikap sains, serta kompetensi sains dalam situasi nyata yang dihadapi siswa. Sedangkan angket tanggapan siswa berupa pernyataan-pernyataan mengenai suatu objek tanggapan yang dapat diberikan dalam bentuk skala rating atau daftar cek. Adapun teknik pengumpulan data berupa tes tertulis dan angket.

Butir soal dikonsultasikan dan divalidasi oleh dosen ahli (judgement expert) dan diuji coba. Soal bentuk pilihan ganda berjumlah 25 soal untuk aspek pengetahuan, dan aspek kompetensi pada konteks pencemaran udara. Sedangkan untuk aspek sikap sains menggunakan skala Likert berjumlah 15 pernyataan. Hasil uji coba soal pilihan ganda dengan koefisien korelasi (rxy) sebesar 0,58 dan koefisien reliabilitas 0,73 (kategori tinggi). Adapun hasil uji coba sikap sains dengan reliabilitas Cronbach's Alpha 0,619 (kategori tinggi).

Peningkatan literasi sains siswa setelah pembelajaran $\mathrm{PjBL}$ STEM diperoleh dengan menghitung nilai rata-rata gain yang dinormalisasi (N_Gain). Hal ini dimaksudkan untuk menghindari kesalahan dalam menginterpretasikan perolehan gain masing-masing mahasiswa/ siswa (Gunawan \& Liliasari, 2013, p. 190). Rumus (Hake, 1998, p. 66) yang digunakan yaitu:

$$
<g>=\frac{\%\left(S_{f}\right)-\%\left(S_{i}\right)}{100-\%\left(S_{f}\right)}
$$

dengan $<g>$ adalah nilai gain ternormalisasi, $S_{f}$ adalah rerata nilai postest, dan $S_{i}$ adalah rerata nilai pretest. Menurut (Hake, 1998, p. 66), interpretasi nilai rata-rata gain yang dinormalisasi adalah $(\langle\mathrm{g}\rangle)<0,3$ dengan kategori rendah; $0,3 \leq(<\mathrm{g}>)<0,7$ kategori sedang; dan $(<\mathrm{g}>) \geq 0,7$ dengan kategori tinggi.

Setelah nilai rata-rata gain yang dinormalisasi untuk kedua kelompok diperoleh, maka selanjutnya dibandingkan untuk melihat perbedaan peningkatan literasi sains siswa untuk kedua kelas. Jika nilai rata-rata gain yang dinormalisasi dari suatu kelas lebih tinggi dari ratarata gain yang dinormalisasi dari kelas lainnya, maka dikatakan bahwa terdapat pengaruh perbedaan gender siswa dalam capaian literasi sains. Uji hipotesis yang digunakan adalah uji- $t$ satu sisi untuk sisi atas. Pada uji-t ini ini menggunakan software SPSS 17 dengan uji-t dua sampel independen. Tujuan uji-t dua variabel adalah untuk membandingkan (membedakan) apakah kedua variabel tersebut sama atau 
berbeda. Gunanya untuk menguji kemampuan generalisasi signifikansi hasil penelitian yang berupa perbandingan dua rata-rata sampel (Riduwan \& Sunarto, 2013, p. 126).

\section{HASIL DAN PEMBAHASAN}

\section{Peningkatan Literasi Sains Siswa}

Soal pretest diberikan sebelum kelas lakilaki dan perempuan mendapatkan perlakuan pembelajaran untuk mengetahui kemampuan awal siswa. Selanjutnya, setelah perlakuan pembelajaran siswa pada kedua diberikan tes literasi sains kembali untuk kedua kalinya. Peningkatan literasi sains siswa pada tema pencemaran udara dihitung menggunakan rumus gain yang dinormalisasi (N_Gain) berdasarkan perolehan data pretest dan posttest.

Perbandingan nilai rata-rata pretest dan posttest literasi sains siswa aspek pengetahuan dan kompetensi tema pencemaran udara pada kelas laki-laki dan kelas perempuan disajikan pada Tabel 1.

Tabel 1. Rekapitulasi Literasi Sains Aspek Pengetahuan dan Kompetensi

\begin{tabular}{lcccc}
\hline & \multicolumn{2}{c}{ Kelas Laki-laki } & \multicolumn{2}{c}{ Kelas Perempuan } \\
\cline { 2 - 5 } & Pretest & Posttest & Pretest & Posttest \\
\hline Nilai Min & 12 & 44 & 20 & $52 *$ \\
Nilai Maks & 64 & $80 *$ & 68 & $80 *$ \\
Rata-rata & 45.79 & $65.52 *$ & 49.00 & 64.57 \\
\hline *capaian nilai tertinggi & & &
\end{tabular}

Berdasarkan Tabel 1 terdapat perbedaan nilai rata-rata literasi sains siswa antara kelas laki-lakidan kelas perempuan. Capaian rata-rata nilai tertinggi aspek pengetahuan dan kompetensi pretest pada kelas laki-laki sebesar 45,79 dari nilai ideal 100 , sedangkan nilai rata-rata pretest kelas perempuan yaitu 49,00. Nilai ratarata posttest kelas laki-laki juga memiliki nilai lebih besar dibandingkan dengan kelas perempuan dengan nilai masing-masing kelas laki-laki dan kelas perempuan yaitu 65,52 dan 64,57.

Aspek sikap sains juga diperoleh skor yang berbeda untuk setiap kelas laki-laki dan perempuan baik untuk sikap sains sebelum diberi perlakuan pembelajaran maupun setelah pembelajaran. Peningkatan sikap sains siswa diperoleh dari gain yang dinormalisasi (N_Gain). Perbedaan capaian sikap sains siswa kelas laki-laki dan kelas perempuan disajikan pada Tabel 2.
Tabel 2. Rekapitulasi Literasi Sains Siswa Aspek Sikap Sains

\begin{tabular}{ccccc}
\hline Kelas & Pretest & Posttest & N_Gain & Kategori \\
\hline Laki-laki & 70.34 & 80.40 & 0.33 & Sedang \\
\hline Perempuan & $70.89 *$ & $82.32 *$ & $0.40 *$ & Sedang \\
\hline * capaian nilai tertinggi & & &
\end{tabular}

Berdasarkan Tabel 2 terdapat perbedaan capaian sikap sains siswa pada kelas laki-laki dan kelas perempuan. Capaian tertinggi pada pretest, posttest dan N_Gain diperoleh kelas perempuan, sedangkan terendah pada kelas lakilaki. Peningkatan kelas laki-laki maupun perempuan pada kategori sedang. Jadi, peningkatan sikap sains siswa kelas perempuan lebih baik dari kelas laki-laki.

Adapun peningkatan nilai rata-rata pretest dan posttest pada masing-masing kelas diwakili oleh perolehan rata-rata gain yang dinormalisasi (N_Gain) kelompok laki-laki dan kelompok perempuan disajikan pada Gambar 1.

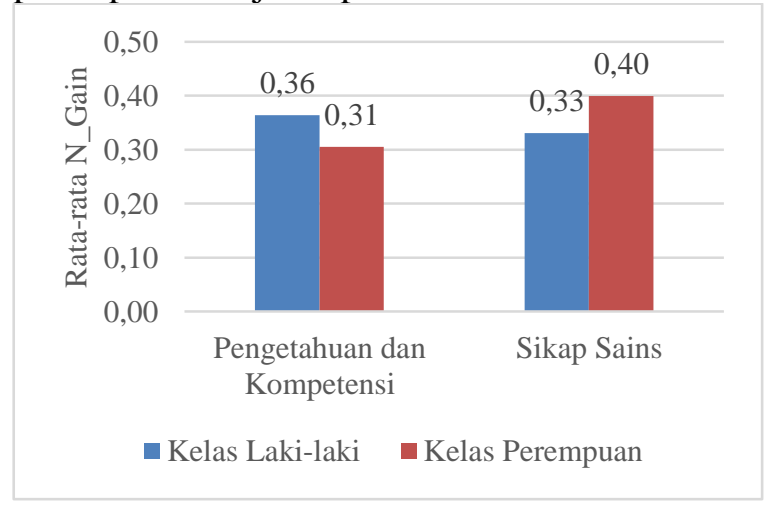

Gambar1. Grafik Rata-rata N_Gain Literasi Sains Aspek Pengetahuan, Kompetensi dan Sikap Sains.

Perbandingan antara kelas laki-laki0,36 (kategori sedang) dankelas perempuan yaitu sebesar 0,31 (kategori sedang). Sedangkan pada aspek sikap sains, kelas perempuan memperoleh capaian lebih tinggi dari kelas laki-laki. Tetapi, perbedaan ini terlebih dahulu harus diuji hipotesis penelitian untuk menentukan signifikansi peningkatan. Apakah perbedaan peningkatan yang terjadi pada kedua aspek literasi sains bermakna atau tidak.

Pengujian hipotesis penelitian untuk mengetahui peningkatan literasi sains setelah mendapatkan pembelajaran PjBL STEM menggunakan uji perbedaan rata-rata $N \_$Gain untuk membandingkan dua sampel independen. Berdasarkan uji prasyarat,data $N \_$Gain literasi sains berdistribusi normal dan bervariansi homogen dengan rekomendasi uji statistik parametrik menggunakan uji t. Adapun hasil uji $t N_{-}$Gain 
literasi sains disajikan pada Tabel 3. Uji hipotesis peningkatan literasi sains siswa sebagai berikut.

$\mathrm{H}_{0}$ : Tidak terdapat perbedaan peningkatan literasi sains antara siswa laki-laki dengan siswa perempuan

$\mathrm{H}_{1}$ : Terdapat perbedaan peningkatan literasi sains antara siswa laki-laki dengan siswa perempuan

Tolak $\mathrm{H}_{0}$ jika $\mathrm{p}$-value/2, (sig.) $<\alpha=0,05$ dan terima $\mathrm{H}_{0}$ jika $\mathrm{p}$-value/2, (sig.) $\geq \alpha=0,05$

Tabel 3. Hasil Uji-t N_Gain Literasi Sains Siswa

\begin{tabular}{lccc}
\hline N_Gain & $\begin{array}{c}\text { Nilai Sig. } \\
\text { (2-tailed) }\end{array}$ & $\alpha$ & Interpretasi \\
\hline $\begin{array}{l}\text { Pengetahuan } \\
\text { dan Kompetensi }\end{array}$ & 0,262 & & $\begin{array}{c}\text { Tidak berbeda } \\
\text { signifikan }\end{array}$ \\
\hline Sikap sains & 0,024 & 0,05 & $\begin{array}{c}\text { Berbeda } \\
\text { signifikan }\end{array}$ \\
\hline
\end{tabular}

Berdasarkan Tabel 3 mendeskripsikan bahwa nilai signifikansi yang diperoleh dari data $N_{-}$Gain literasi sains siswa kelas laki-laki dan kelas perempuan aspek pengetahuan dan kompetensi sains lebih besar (sig. $=$ p-value $/ 2=$ $0,262 / 2=0,131)$ dari $\alpha($ sig. $0,131>(\alpha) 0,05)$, maka $\mathrm{Ho}$ diterima dan $\mathrm{H}_{1}$ ditolak. Artinya, tidak terdapat perbedaan signifikan peningkatan literasi sains siswa aspek pengetahuan dan kompetensi. Sedangkan $N_{-}$Gain sikap sains siswa dengan nilai sig. $=\mathrm{p}$-value $/ 2=0,024 / 2=0,012$. Sig. $0,012<(\alpha) 0,05$, maka $\mathrm{H}_{1}$ diterima, berarti terdapat perbedaan signifikan antara kelas lakilaki dan kelas perempuan. Dengan demikian dapat disimpulkan bahwa tidak terdapat perbedaan yang signifikan peningkatan literasi sains siswa aspek pengetahuan dan kompetensi antara kelas laki-laki dan kelas perempuan dengan penerapan PjBL STEM. Sedangkan peningkatanskor sikap sains berbeda signifikan antara kelas laki-laki dan kelas perempuan.

\section{Deskripsi Peningkatan pada Tiap Aspek Literasi Sains}

Soal literasi sains yang dikembangkan pada aspek pengetahuan yaitu: Polusi Udara (PU) dan Efek Rumah Kaca (ERK). Sedangkan aspek kompetensi yaitu: Mengidentifikasi Isu Ilmiah (MII), Menjelaskan Fenomena Ilmiah (MFI), Menggunakan Bukti Ilmiah (MBI). Secara keseluruhan tema pencemaran udara merupakan aspek konteks sains.

Deskripsi peningkatan pada tiap indikator aspek literasi sains siswa yang diwakili oleh rata-rata $N$ _Gain masing-masing indikator untuk kelas laki-laki dan kelas perempuandisajikan pa- da Gambar 2. Dari Gambar 2 diperoleh deskripsi bahwa nilai $N_{-}$Gain untuk aspek pengetahuan kelas laki-laki lebih baik dari kelas perempuan. Sedangkan pada aspek kompetensi, kelas lakilaki lebih unggul dari kelas perempuan hanya pada indikator mengidentifikasi isu ilmiah Sedangkan indikator menggunakan bukti ilmiah dan menjelaskan fenomena ilmiah kelas perempuan lebih unggul.

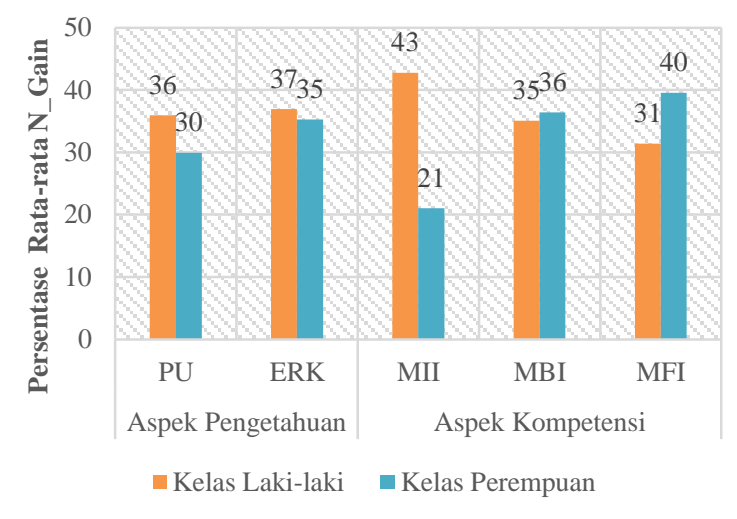

Keterangan: PU: Polusi Udara; ERK: Efek Rumah Kaca; MII: Mengidentifikasi Isu Ilmiah;MBI: Menggunakan Bukti Ilmiah dan MFI: Menjelaskan Fenomena Ilmiah.

Gambar 2. Grafik Persentase Rata-Rata $N_{-}$Gain Tiap Indikator Literasi Sains

Hasil temuan ini ekuivalen dengan capaian prestasi siswa Indonesia pada PISA 2006. Tjalla (2010, p.13) menyatakan bahwa kemampuan literasi sains rata-rata siswa Indonesia lakilaki (skor 399) lebih tinggi daripada kemampuan literasi sains rata-rata siswa Indonesia perempuan (skor 387). Siswa yang memperoleh skor tes sains tinggi cenderung mempunyai sikap yang lebih positif terhadap sains (Ekohariadi \& Salim, 2010, p. 42).

Namun capaian aspek kompetensi pada indikator menjelaskan fenomena ilmiah (MFI) kelas perempuan lebih tinggi dari kelas laki-laki. Perbedaan ini mungkin disebabkan karena perempuan lebih banyak meluangkan waktu untuk belajar sains dan menyenangi belajar sains. Sehingga capaian eksplanasi ilmiah atau menjelaskan fenomena ilmiah lebih baik. Seperti yang diungkapkan oleh (Evans, 2012), hasil survei General Certificate of Secondary Education (GCSE) menunjukkan bahwa pelajaran kimia dan biologi lebih baik untuk anak perempuan, dan pelajaran fisika sama untuk keduanya, sedangkan laki-laki lebih unggul di matematika. Tema pencemaran udara yang diajarkan lebih cenderung ke biologi, meskipun pada materi efek rumah kaca termasuk dalam bidang kajian 
fisika. Jadi dapat dikatakan bahwa tema pencemaran udara cenderung lebih disenangi perempuan.

Bila dianalisis dari aspek sikap sains, peningkatan tiap indikator sikap sains siswa dideskripsikan dalam bentuk persentaseN_Gain masing-masing indikator untuk kelas laki-laki dan kelas perempuan ditunjukkan oleh Gambar 3.

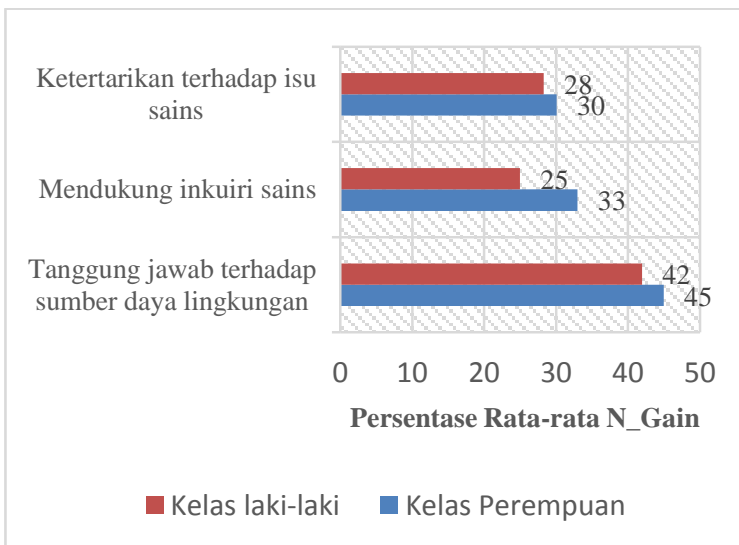

Gambar 3. Grafik Persentase Rata-Rata $N_{-}$Gain Tiap Indikator Sikap Sains Siswa

Berdasarkan Gambar 3 mendeskripsikan peningkatan sikap sains siswa setelah mendapatkan pembelajaran sains tema pencemaran udara. Perbedaan gender berdampak pada peningkatan skor sikap sains siswa. Secara keseluruhan, peningkatan sikap sains kelas perempuan lebih baik dari kelas laki-laki.

Siswa perempuan lebih tertarik terhadap isu sains, mendukung inkuiri sains, dan tanggung jawab terhadap sumber daya lingkungan. Hasil ini didukung dengan meningkatnya capaian indiktor sains (S) pada aspek STEM. Kelas perempuan lebih unggul 7 point pada persentase rata-rata $N \_$Gain dari kelas laki-laki. Salah satu faktor meningkatnya aspek sikap sains kelas perempuan lebih baik daripada kelas laki-laki adalah perbedaan gender. Hasil ini didukung oleh (Larson, Stephen, Bonitz, \& Wu, 2014, p. 89) bahwa gender memoderasi hubungan ketertarikan dengan prestasi belajar. Siswa laki-laki yang lebih tertarik pada fisika dan kimia mencapai skor prestasi yang lebih tinggi, namun tingkat ketertarikan siswa perempuan tidak berkorelasi dengan prestasi belajar. Karena perempuan lebih senang belajar biologi atau sains terkait pilihan pekerjaan di masa depan (Hango, 2013, p. 7). Hal ini sejalan dengan apa yang diungkapkan (Ekohariadi \& Salim, 2010, p. 42), tinggi ren-dahnya sikap siswa terhadap sains dipengaruhi secara positif diantaranya adalah pekerjaan yang diinginkan siswa, kegiatan belajar mengajar di kelas, dan banyaknya waktu yang digunakan untuk belajar sains.

Untuk mengetahui perbedaan gender terhadap peningkatan soal literasi sains yang bermuatan aspek STEM, perlu dilakukan analisis temuan pada data $N_{-}$Gainkelas laki-laki dan kelas perempuan. Keterpaduan aspek STEM dalam soal meliputi aspek sains (S), sainsteknologi (S-T), sains- matematika (S-M), dan sains-teknologi-engineering $(\mathrm{S}-\mathrm{T}-\mathrm{E})$.

Peningkatan aspek STEM tiap indikator soal disajikan pada Gambar 4.

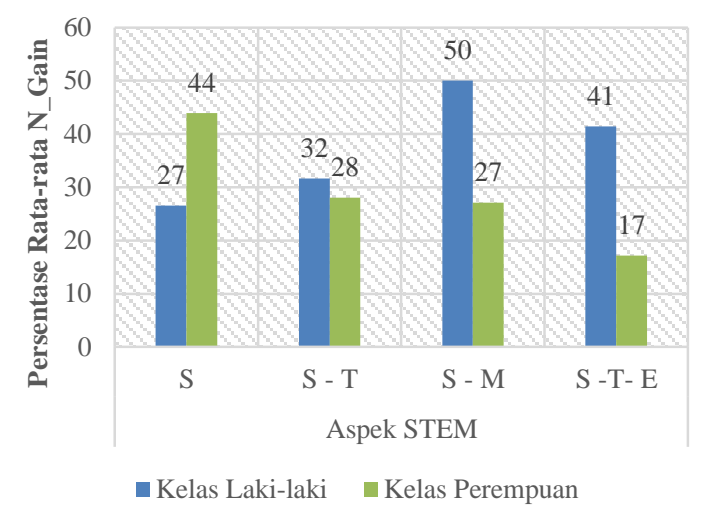

Keterangan: S: sains; S-T: sains-teknologi; S-M: sains-matematika; dan S-T-E: sains-teknologiengineering.

\section{Gambar 4. Grafik Persentase Rata-RataN_Gain Tiap Indikator Aspek STEM}

Berdasarkan Gambar 4 mendeskripsikan peningkatan aspek STEM yang dipadukan dalam soal literasi sains siswa. Capaian tertinggi pada kelompok laki-laki pada indikator sainsmatematika (S-M) sebesar 50\% dan terendah pada indikator sains yaitu sebesar $27 \%$. Sedangkan untuk kelompok perempuan, capaian paling tinggi sebesar $44 \%$ pada indikator sains dan paling rendah pada indikator sains-teknologiengineering (S-T-E) yaitu sebesar $17 \%$. Secara keseluruhan, kelompok laki-laki lebih unggul pada indikator S-T, S-M, dan S-T-E, sedangkan kelompok perempuan lebih unggul pada indikator sains $(\mathrm{S})$.

Kedua kelompok kelas diajar dengan PjBL STEM dimana teknologi, engineering, dan matematika dipadukan untuk membelajarkan sains. Capaian peningkatan aspek STEM sangat berpengaruh terhadap sikap sains siswa. Kelas laki-laki lebih unggul pada indikator sains-teknologi (S-T), sains-matematika (S-M), dan sains-teknologi-engineering (S-T-E). Sedangkan kelas perempuan unggul untuk indikator sains saja. 
Hasil penelitian ini didukung oleh hasil PISA 2012 mengemukakan bahwa laki-laki unggul dibandingkan perempuan dalam kinerja matematika. Perempuan merasa kurang termotivasi untuk belajar matematika dan kurang yakin pada kemampuannya dibandingkan dengan laki-laki. Hal ini yang menjadi tantangan berat untuk mencapai kesetaraan gender pada bidang pekerjaan STEM di masa depan (OECD, 2014, p.9). Untuk bidang teknologi dan engineering, Hango, (2013, p. 7) menyebutkan bahwa bidang STEM didominasi oleh laki-laki. Perempuan kebanyak-an memilih bidang biologi atau sains, sehingga lebih sedikit memilih bidang engineering, ilmu komputer, dan matematika. Jika laki-laki lebih banyak memilih dalam bidang STEM, itu bukan karena laki-laki memiliki skor PISA lebih baik daripada perempuan. Bahkan, ketika diukur kemampuan matematika digabungkan dengan variabel lain, perbedaan gender tetap signifikan.

(Kulturel-Konak, D'Allegro, \& Dickinson, 2011, pp. 15-16) menyimpulkan perempuan cenderung lebih suka pengalaman belajar hands-on, membuat penilaian intuitif berdasarkan perasaan, selalu berorientasi, dan merasa nyaman dengan ambiguitas. Sedangkan laki-laki cenderung melakukan analisis dalam pembelajaran, berpikir logis dan rasional, dan menikmati bekerja dengan simbol seperti struktur. Bidang STEM mencerminkan pendekatan analitis sehingga cenderung lebih sesuai bagi laki-laki.

Bagaimanapun, anak laki-laki dan anak perempuan tampaknya memiliki kemampuan kognitif yang hampir sama. Pada aspirasi karir, anak perempuan lebih cenderung memilih karir yang tidak akan mengganggu perannya di masa depan sebagai pasangan atau orang tua. Sementara anak laki-laki memiliki harapan jangka panjang yang lebih tinggi untuk diri mereka sendiri (Ormrod, dalam Arends, 2012, p. 77).

\section{Tanggapan Siswa Terhadap PjBL STEM}

Untuk mengetahui tanggapan siswa terhadap penerapan pembelajaran PjBL STEM pada tema pencemaran udara digunakan angket skala sikap. Tanggapan siswa terhadap pembelajaran diberikan setelah tahapan PjBL STEM selesai seluruhnya. Distribusi pernyataan angket tanggapan siswa terhadap pembelajaran tema pencemaran udara terbagi ke dalam empat indikator yaitu senang dan memberi motivasi lebih dengan penerapan model; membantu memahami, membentuk sikap kreatif, dan semakin menya- dari pentingnya menjaga lingkungan; merasa senang dalam berkelompok; serta mempunyai keinginan untuk menggunakan kembali model pembelajaran tersebut. Pemberian angket tentang penerapan PjBL STEM bertujuan untuk mengumpulkan data tanggapan siswa terhadap model pembelajaran tersebut, sehingga diperoleh kecenderungan atau arah sikap siswa setelah pembelajaran selesai dilaksanakan pada kelas eksperimen. Skala sikap yang digunakan terdiri atas 10 butir pernyataan positif.

Persentase rata-rata tanggapan siswa pada tiap indikator pernyataannya. Rincian persentase tanggapan siswa tersebut yaitu sebesar $72,50 \%$ siswa laki-laki dan $79,31 \%$ siswa perempuan merasa senang, dan termotivasi belajar pada tema pencemaran udara dengan PjBL STEM; sebesar $77,71 \%$ siswa laki-laki dan $81,68 \%$ siswa perempuan berpendapat bahwa penerapan PjBL STEM dapat membantu memahami tema pencemaran udara, membentuk sikap kreatif, dan semakin menyadari pentingnya menjaga lingkungan; sebesar 75,42\% siswa laki-laki dan $81,03 \%$ siswa perempuan merasa senang dengan kegiatan dalam kelompoknya, serta 77,50\% siswa laki-laki dan 81,03 siswa perempuan mempunyai keinginan untuk mengikuti kembali pembelajaran PjBL STEM pada tema lain. Sehingga rata-rata skor tanggapan siswa terhadap penerapan PjBL STEM secara keseluruhan adalah sebesar 75,78\% untuk siswa laki-laki dan $80,77 \%$ untuk siswa perempuan. Dengan demikian dapat disimpulkan bahwa hampir seluruh siswa laki-laki maupun perempuan memberikan respon positif dan senang terhadap penerapan PjBL STEM pada tema pencemaran udara selama kegiatan penelitian.Agar lebih memperjelas kecenderungan sikap siswa laki-laki dan siswa perempuanterhadap PjBL STEM diilustrasikan pada Gambar 5.

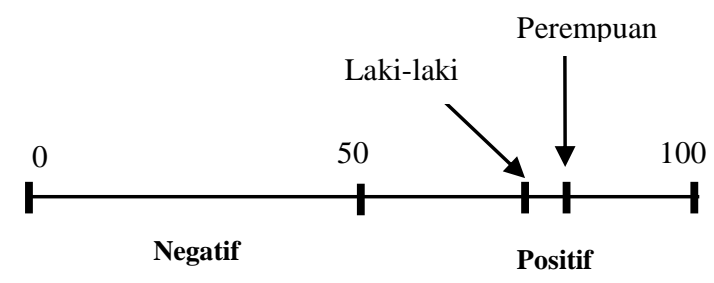

\section{Gambar 5. Persentase Sikap Siswa Terhadap} PjBL STEM

Berdasarkan hasil pengolahan angket secara keseluruhan menunjukkan bahwa hampir seluruh siswa menyatakan setuju terhadap penerapan PjBL STEM dalam pembelajaran tema pencemaran udara. Hal ini sejalan dengan 
penelitian Baran \& Maskan (2010, p.252) yang bertujuan untuk mengetahui pengaruh $\mathrm{PjBL}$ terhadap hasil belajar elektrostatis mahasiswa calon guru fisika, ditemukan bahwa mahasiswa lebih aktif bila diajar menggunakanPjBL dan memilikiwaktu pembelajaran yang lebih menyenangkan. Penelitian lain juga berpendapat sama, bahwa PjBL merupakan pembelajaran yang menarik dan menyenangkan (Yalçin, Turgut, \& Büyükkasap, 2009, p. 101; Kemdikbud, 2014, p.33). Dengan demiki-an, melalui penerapan PjBL STEM diharapkan siswa mendapatkan pengalaman baru sehingga menimbulkan motivasi dan minat dalam mempelajari tema pencemaran udara

\section{SIMPULAN DAN SARAN}

\section{Simpulan}

Literasi sains siswa kelas laki-laki dan kelas perempuan sama-sama mengalami peningkatan dengan rerata N_Gain berturut-turut 0,36 dan 0,31 (dalam kategori sedang) untuk aspek pengetahuan, dan kompetensi. Peningkatanaspek sikap sains padakelas perempuan lebih tinggi dibandingkan dengan kelas laki-laki.

Siswa baik laki-laki maupun perempuan menunjukkan respon positif dan senang terhadap penerapan PjBL STEM dalam pembelajaran pencemaran udara. Menurut siswa, pembelajaran menarik dan memotivasi; dapat membantu memahami materi ajar, membentuk sikap kreatif, dan siswa semakin menyadari pentingnya menjaga lingkungan. Siswa merasa senang bekerja dalam kelompok sehingga mereka berkeinginan pembelajaran PjBL STEM dapat diterapkan kembali pada materi lain.

\section{Saran}

Pembelajaran di sekolah hendaknya melatih kemandirian belajar siswa dengan menggunakan model pembelajaran yang berpusat pada siswa (student center), seperti PjBL STEM. Namun, guru juga harus melakukan perbaikan penilaian hasil belajar, salah satunya dengan mengembangkan soal literasi sains dan siswa harus dibiasakan dengan soal-soal yang memiliki framework seperti pada soal PISA.

Penerapkan PjBL STEM untuk meningkatkan literasi sains dapat dilanjutkan pada materi sains yang mempunyai karakteristik STEM. Penelitian tentang gender agar membandingkan dua tipe sekolah yang berbeda, missalnya sekolah khusus dengan sekolah umum. Sekolah khusus memisahkan kelas berdasarkan jenis kelamin (kelas homogen gender), sedangkan sekolah umum mencampurkan jenis kelamin dalam satu kelas (kelas heterogen gender).

\section{DAFTAR PUSTAKA}

Arends, R. (2012). Learning to teach (9th Editio). New York: The McGraw-Hill Companies, Inc.

Capraro, R. M., Capraro, M. M., Morgan, J. R., \& Slough, S. W. (2013). STEM ProjectBased Learning: An Integrated Science, Technology, Engineering, and Mathematics (STEM) Approach. STEM Project-Based Learning an Integrated Science, Technology, Engineering, and Mathematics (STEM) Approach. http://doi.org/10.1007/978-94-6209-143-6

Baran, M. \& Maskan, A. (2010). The Effect of project-based learning on pre-service physics teachers' electrostatic achievements. Cypriot Journal of Educational Sciences, 5, 243-257.

Cook, K., Buck, G., \& Park Rogers, M. (2012). Preparing biology teachers to teach evolution in a project-based approach. Science Educator, 21(2), 18-30. Retrieved from https://eric.ed.gov/?id=EJ997503

Dugger, W. E. (2010). Evolution of STEM in the United States. 6Th Biennial International Conference on Technology Education Research, (March), 1-8. http://doi.org/10.1.1.476.5804

Ekohariadi, \& Salim, A. (2010). Perkembangan kemampuan sains siswa indonesia usia 15 tahun berdasarkan data studi PISA. Jakarta: Pusat Penilaian Pendidikan Badan Penelitian dan Pengembangan Kementerian Pendidikan Nasional.

Evans, L. (2012). GCSE results 2012: exam breakdown by subject, gender and area. Retrieved February 4, 2017, from https://www.theguardian.com/news/databl og/2012/aug/23/gcse-results-2012-exambreakdown

Gunawan, G., \& Liliasari, L. (2013). Model virtual laboratory fisika modern untuk meningkatkan disposisi berpikir kritis calon guru. Jurnal Cakrawala Pendidikan, $X X X I(2)$, 185-199. http://doi.org/10.21831/CP.V5I2.1556

Firman, H. (2015). Pendidikan sains berbasis STEM: Konsep, pengembangan, dan peranan riset pascasarjana. Disampaikan 
pada Seminar Nasional Pendidikan IPA dan PLKH Universitas Pakuan, Agustus 2015. Bandung: Universitas Pendidikan Indonesia

Fraenkel, J.R., Wallen, N.E., \& Hyun, H.N. (2011).How to design and evaluate research in education (eighth ed.). New York: Mc. Graw Hill.

Glencoe. (2005). The Air around you. US: McGraw-Hill Inc

Hake, R. R. (1998). Interactive-engagement versus traditional methods: A sixthousand-student survey of mechanics test data for introductory physics courses. American Journal of Physics, 66(1), 6474. http://doi.org/10.1119/1.18809

Han, S., Capraro, R., \& Capraro, M. M. (2015). How science, technology, engineering, and mathematics (STEM) project-based learning (PBL) affects high, middle, and low achievers differently: The Impact of student factors on achievement. International Journal of Science and Mathematics Education, 13(5), 10891113. http://doi.org/10.1007/s10763-0149526-0

Hango, D. (2013). Gender differences in science, technology, engineering, mathematics and computer science (STEM) programs at university Insights on Canadian Society. In Insights on Canadian Society (pp. 1-11). Statistics Canada.

Hewitt, et al. (2013). Conceptual integrated science (second ed). USA: Pearson Education

Kemdikbud. (2013). Ilmu pengetahuan alam untuk SMP/MTs kelas VII: Buku Guru. Jakarta: Kementerian Pendidikan dan Kebudayaan

Kemdikbud. (2014). Materi pelatihan guru implementasi kurikulum 2013 tahun ajaran 2014/2015: Mata pelajaran IPA SMP/MTs. Jakarta: Kementerian Pendidikan dan Kebudayaan

Kilınç, A. (2010). Can project-based learning close the gap? Turkish student teachers and proenvironmental behaviours. October, 5(4), 495-509.

Kulturel-Konak, S., D'Allegro, M. Lou, \& Dickinson, S. (2011). Review of gender differences in learning styles: Suggestions for STEM education. Contemporary Issues in Education Research (CIER), 4(3), 9-18. http://doi.org/10.19030/cier.v4i3.4116

Laboy-Rush, D. (2010). Integrated STEM education through project-based learning. www.learning.com/stem/whitepaper/integ rated-STEM-through-Project-based-

Learning.

Larson, L. M., Stephen, A., Bonitz, V. S., \& $\mathrm{Wu}$, T.-F. (2014). Predicting science achievement in India: Role of gender, selfefficacy, interests, and effort. Journal of Career Assessment, 22(1), 1-25. http://doi.org/doi:10.1177/1069072713487 975

Mayasari, T., Kadorahman, A., \& Rusdiana, D. (2014). Pengaruh pembelajaran terintegrasi science, technology, engineering, and mathemathics (STEM) pada hasil belajar peserta didik: Studi meta analisis, Prosiding Semnas Pensa VI "Peran Literasi Sains" (p.371-377). Surabaya: UNESA

Movahedzadeh, F., Patwell, R., Rieker, J. E., \& Gonzalez, T. (2012). Project-based learning to promote effective learning in biotechnology courses. Education Research International, 2012, 1-8. http://doi.org/10.1155/2012/536024

National Research Council. (2011). A Framework for K-12 Science Education: Practices, Crosscutting Concepts, and Core Ideas. Washington DC: The National Academies Press

Odja, A. H., \& Payu, C. S. (2014). Analisis kemampuan awal literasi sains siswa pada konsep IPA. In Prosiding Seminar Nasional Kimia (pp. 40-47). Surabaya: Jurusan Kimia FMIPA Universitas Negeri Surabaya.

OECD. (2014). PISA 2012 results in focus: What 15-year-olds know and what they can do with what they know. OECD Publishing

Özer, D. Z. dan Özkan, M. (2012). The Effect of the project based learning on the science process skills of the prospective teachers of science. Journal of Turkish Science Education, 9 (3), 131-136.

Raven, P.H., Hassenzahl, D.M., \& Berg, L.R. (2013). Environment: international student version (eight ed). Singapura: John Wiley \& Son 
Riduwan \& Sunarto. (2013). Pengantar statistika untuk penelitian: Pendidikan, social, komunikasi, ekonomi, dan bisnis (cetakan keenam). Bandung: Alfabeta

Reeve, E.M. (2015). STEM thinking!. Technology and Engineering Teacher(ITEEA), 74 (4), 8-16.

Stohlmann, M., Moore, T. J., \& Roehrig, G. H. (2012). Considerations for teaching integrated STEM education. Journal of Pre-College Engineering Education Research Journal of Pre-College Engineering Education ResearchJ-PEER) Journal of Pre-College Engineering Education Research, 2(2), 1-28. http://doi.org/10.5703/1288284314653

Sugiyono. (2013). Metode penelitian pendidikan (pendekatan kuantitatif, kulaitatif, dan $R$ \& D). Bandung : Alfabeta

Sukmadinata, N.S. (2010). Metode penelitian pendidikan. Bandung: Remaja Rosdakarya

Tjalla, A. (2010). Potret Mutu Pendidikan Indonesia Ditinjau dari Hasil-hasil Studi
Internasional. [Online]. Diakses dari http://pustaka.ut.ac.id/pdfartikel/TIG601.p df

Toharudin, U., Hendrawati, S., \& Rustaman, A. (2011). Membangun literasi sains peserta didik (cetakan pertama). Bandung: HumanioraTseng, K.-H., Chang, C.-C., Lou, S.-J., \& Chen, W.-P. (2013). Attitudes towards science, technology, engineering and mathematics (STEM) in a project-based learning (PjBL) environment. International Journal of Technology and Design Education, 23(1), 87-102. http://doi.org/10.1007/s10798011-9160-x

Yalçin, S. A., Turgut, Ü., \& Büyükkasap, E. (2009). The effect of project based learning on science undergraduates' learning of electricity, attitude towards physics and scientific process skills. International Online Journal of Educational Sciences, 1(1), 81-105. Retrieved from http://www.iojes.net//userfiles/Article/IOJ ES_134.pdf 